\title{
The OECD enlargement in Latin America and the Brazilian candidacy
}

DOI: http://dx.doi.org/10.1590/0034-7329202000211

Rev. Bras. Polít. Int., 63(2): e011, 2020

Revista Brasileira de Política Internacional ISSN 1983-3121

http://www.scielo.br/rbpi

\section{Flavia de Campos Mello ${ }^{1}$}

${ }^{1}$ Pontifícia Universidade Católica de São Paulo, São Paulo, SP, Brazil (fmello@pucsp.br).

\section{Copyright:}

- This is an open-access article distributed under the terms of a Creative Commons Attribution License, which permits unrestricted use, distribution, and reproduction in any medium, provided that the original author and source are credited.

- Este é um artigo publicado em acesso aberto e distribuído sob os termos da Licença de Atribuição Creative Commons, que permite uso irrestrito, distribuição e reprodução em qualquer meio, desde que o autor e a fonte originais sejam creditados.
Received: April 9, 2020

Accepted: August 19, 2020

\section{Introduction}

$A_{\text {of Brazilian foreign policy since the impeachment of }}^{\text {mong the initiatives that have expressed the reorientation }}$ President Dilma Rousseff, the country's decision to become a member of the Organization for Economic Cooperation and Development (OECD) might appear, in symbolic terms, as the most evident indication of an international project directed towards the acceptance of global governance mechanisms promoted by developed countries. Originally known as "the club of the rich," the organization has acquired a new profile regarding the more diversified composition of its members in recent years. It is, nonetheless, a peculiar multilateral institution, where membership selection is based on the internalization of a whole set of liberalizing economic norms already previously embodied in the organization, 
as well as the promotion of closer political relations with its members, especially the United States and the major economies of the European Union, reflecting the transatlantic alliance of the post-World War II period, which is at the origin of its foundation. The functioning of the organization is also peculiar, as it allows the participation of non-member countries in its technical committees if approved by members. Brazil became the most active non-member country in terms of participation, both in committees and legal instruments in the organization (Organization for Economic Co-operation and Development 2018b, 8; Ministério das Relaçóes Exteriores 2020).

Brazil formally presented its candidacy to become a full member of the OECD in May 2017, during the Michel Temer administration, with high expectations that the initial process could be accelerated and concluded before the end of his term, in December 2018. Nonetheless, there was an important previous step taken while President Dilma Rousseff was still in office, when the Brazil-OECD Cooperation Agreement was signed in 2015. It had resulted from an intense mobilization on the part of the Ministry of Finance, under an administration already more committed to a liberal economic agenda than its predecessors, revealing that a reorientation of the country's foreign economic relations was underway even before the change of government which took place after the impeachment process in 2016.

This article reviews the previous history and stages of the enlargement process in the OECD, in order to understand its contemporary features and its extent in Latin America, focusing on the Brazilian candidacy. It examines how membership accession in the OECD reflects a specific configuration of multilateralism, which, since the first decade of the XXI century, has tried to boost participation from emerging and developing countries by having the compromise to the most consolidated agenda of liberalizing economic reforms embodied in contemporary global governance. The following sections review the origins of the OECD and the successive phases of enlargement, which led to increased heterogeneity among its members and new relations with non-member countries. The article then looks specifically at the Brazilian candidacy, which was preceded by the so-called "Enhanced Engagement" launched by the OECD in 2007 towards a group of emerging countries, and later embraced at the domestic level as part of the significant change of orientation regarding economic reforms and foreign policy choices. The following section situates the experience of Latin American countries regarding their accession processes to the OECD in the context of the role played by the United States. The final section concludes by referring to the OECD as an expanding Western-led institution aimed at promoting a liberal economic agenda through enhanced global governance mechanisms.

\section{The origins of the OECD and the enlargement process}

The OECD was formally created in 1961, having as its predecessor the Organization for European Economic Cooperation (OEEC), the institution founded in 1948 to coordinate the implementation of economic aid granted by the United States to European reconstruction, under 
the Marshall Plan. In addition to the 18 founding members of the OEEC ${ }^{1}$, the OECD was born under the aegis of the transatlantic alliance, incorporating the United States and Canada as its members and broadening the original focus on European reconstruction to encompass a mandate to promote economic development, although maintaining the codes of trade liberalization and monitoring procedures which were already in place in the original institutional design (Carroll and Kellow 2011; Clifton and Diaz-Fuentes 2011). It is therefore this way that the OECD, possibly in a more direct way than any of the other institutions founded in the post-World War II period, has fully reflected the structures of the western economic order during the Cold War (Patrick and Egel 2015). In the following years, new members have been admitted. Japan in 1964, Finland in 1969, Australia in 1971 and New Zealand in 1973, conferring a global reach to an institutional arrangement which was originally Western European and North American.

Throughout the Cold War, the OECD strengthened its role as a forum for promoting convergent norms and standards in a great variety of areas, which nowadays encompasses, among others, regulations on international investment and multinational enterprises, trade, taxation, competition policies, public governance, corporate governance, anti-corruption measures, intellectual property rights, labor and environmental standards, education and health policies and anti-terrorism financial measures. Its influence, however, has always extended beyond its members, as the norms agreed upon in the organization tend to become the standards its members will propose in broader international institutions, such as the UN-system agencies and the successive rounds of trade negotiations in the General Agreement on Tariffs and Trade (GATT), and later the World Trade Organization (WTO).

In that sense, the OECD has frequently played the role of an informal and exclusive pre-negotiation forum among developed countries, of norms and patterns only subsequently submitted to more institutionalized and universal negotiating processes in other institutions. Although it has not always been the locus itself of the universalization of the norms agreed upon by its members, it has played a crucial role in selecting the issues that should become part of the international governance agenda, as well as defining the specific content of the rules to be adopted from the perspective of a developed country. Especially in the 1980s, when the so-called new issues where incorporated to the GATT negotiations (trade in services, trade-related investment measures and trade-related intellectual property measures), the OECD had been the agenda-settler forum for the expansion of international economic governance, promoting a cohesive position among developed countries that was subsequently proposed along a North-South cleavage in the multilateral universalist negotiations of the Uruguay Round (Mello 2011). At the celebration marking the OECD's $30^{\text {th }}$ anniversary, in 1991, one of the directors summarized the specific functioning of the institution when pronouncing that "a great advantage of the OECD is that it has no power but great influence" (Woodward 2009).

\footnotetext{
${ }^{1}$ Austria, Belgium, Denmark, France, Germany, Greece, Iceland, Ireland, Italy, Luxembourg, the Netherlands, Norway, Portugal, Spain, Sweden, Switzerland, Turkey and the United Kingdom
} 
Against this background, the end of the Cold War has given renewed impetus to the OECD's expanding role in the new international scene. Between 1994 and 2000, the organization has admitted six new members: Mexico (1994), the Czech Republic (1995), Poland (1996), Hungary (1996), Korea (1996) and the Slovak Republic (2000).

In the case of Mexico, accession to the OECD took place simultaneously to the implementation of the North American Free Trade Agreement (NAFTA), expressing the symbolic and practical dimensions of the country's new relations with North America and developed countries, as well as its commitment to economic liberalization and market reforms. In the case of the four Eastern Europe countries, accession to the OECD has preceded their membership in the European Union. Both Mexico and Korea, when acceding to the OECD, were formally required to withdraw from the G77, in which they were founding members, reflecting the view that belonging to these groupings were mutually exclusive strategies.

The following phase in the enlargement process of the OECD was launched in 2007 and concluded in 2010, with the accession of Israel, Chile, Slovenia and Estonia, establishing a pattern in which the acceptance of each new European member involves the simultaneous acceptance of a country from a different region, in order to avoid an imbalance in favor of Europe in the organization. Also, in 2007, the OECD initiated Russia's halting accession process, which was indefinitely suspended in 2014 , as a reaction to the invasion of Crimea. ${ }^{2}$

\section{Participation of Non-Members}

The third dimension of the new strategies implemented in 2007 was the so-called Enhanced Engagement, a program planned for increasing contacts between the OECD and five selected non-member countries: Brazil, China, India, Indonesia e South Africa (Council at Ministerial Level 2007). This initiative can be understood as an attempt to promote flexible patterns of relations with some of the rising powers of the first decade of the $21^{\text {st }}$ century, namely Indonesia and the members of the Brazil, Russia, India, China, South Africa group (BRICS), even before its institutionalization as a formal mechanism ${ }^{3}$, in the context of still optimistic expectations at that time, regarding the possibilities of absorbing emerging countries in some expanded version of a liberal Greater West (Hurrell 2013). The program was redimensioned in 2012, granting these countries the status of Key Partners and establishing a halfway category between full

\footnotetext{
${ }^{2}$ Russia, as well as Brazil, had previously signaled, in the 1990s, an interest in being admitted to the OECD. At the G7 Summit in June 1995, as a way to reinforce the purpose of closer relations with western countries and his commitment to economic reforms, President Boris Yeltsin had declared that Russia intended to become a member of the OECD, at the same time, President Fernando Henrique Cardoso expressed the same interest. From 2007 to 2014, by the time its accession process was indefinitely suspended, Russia had only displayed a very limited interest in moving forward towards the convergence of its domestic legislation with the OECD's practices and norms.

${ }^{3}$ In 2006, Brazil, Russia, India and China had a first informal meeting of foreign ministers, organized on the sidelines of the $61^{\text {st }}$ General Assembly of the United Nations, leading in 2008 to a first formal meeting of foreign ministers, and in 2009 to the first summit at heads of State/Government level. In 2011, after South Africa's entry, the grouping became BRICS (with the uppercase " $\mathrm{s}$ " at the end).
} 
membership and disengagement, as well as several mechanisms for closer relations and possible channels of influence. ${ }^{4}$ The results were highly heterogeneous, with Brazil and South Africa showing greater receptivity, China and India revealing a much more restricted response, and the weaker situation of Indonesia in terms of capacity to engage in a process of convergence of its domestic practices with the legal framework of the OECD (Patrick and Egel 2015; Clifton and Diaz-Fuentes 2014).

Since 2012, the participation of non-members in OECD activities has been particularly valued by the organization and classified under three categories: guests, participants and associates, according to the level of implication and the payment of quotas in the last two cases. As an associate, a non-member country can participate in full terms in the activities of the committees and subsidiary bodies of the organization, and even take part in the decision-making process of the body in which it has been accepted, with almost all the same rights and obligations of the member countries, including the commitment to implement its decisions. What differs them from full member countries is not taking part in activities related to the accession processes of new members in the organization (Organization for Economic Co-operation and Development 2015).

Figure 1. Number of Non-Member Adherences to OECD Legal Instruments

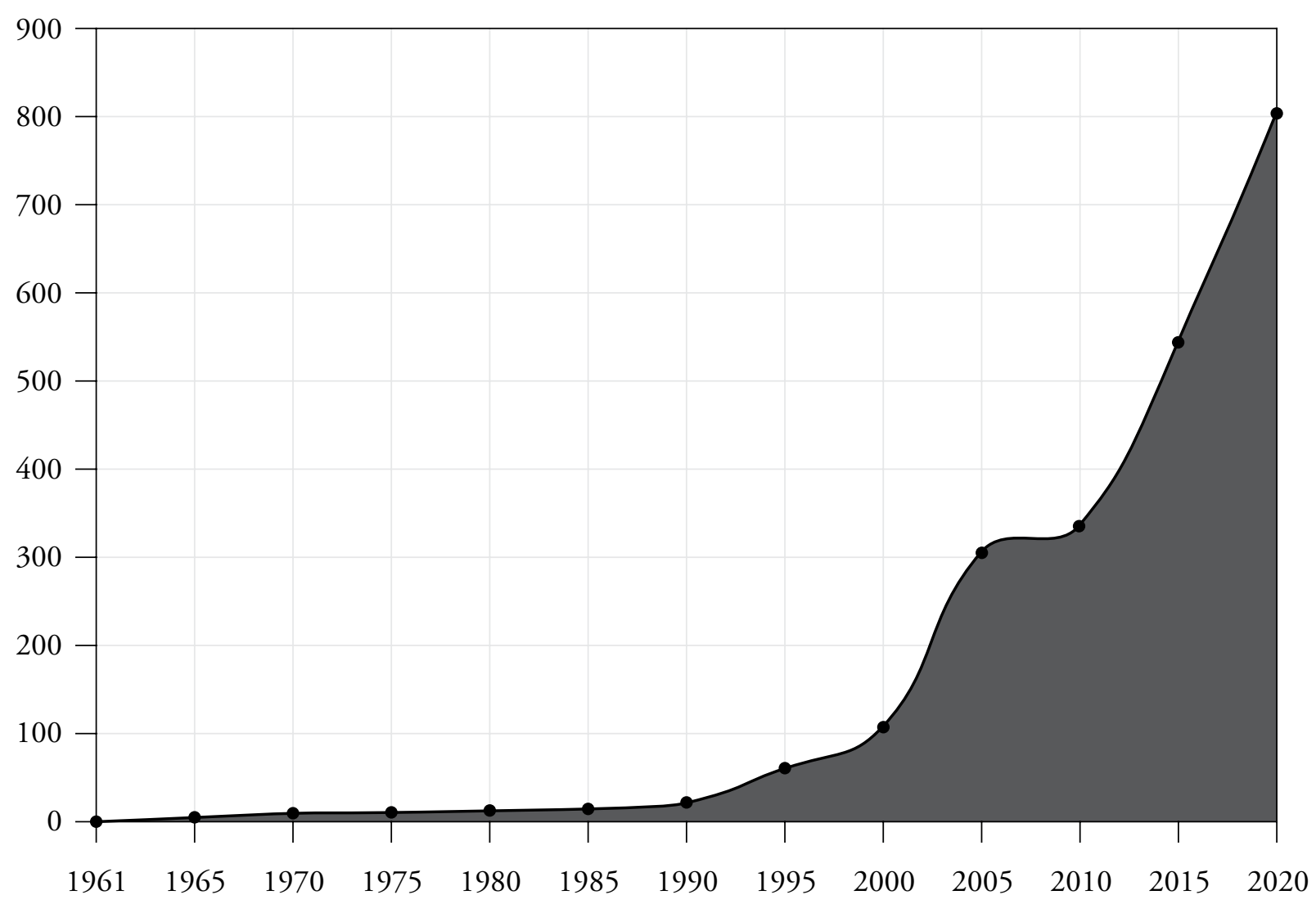

Source: Organization for Economic Co-operation and Development (2020c)

\footnotetext{
${ }^{4}$ For an analysis on the strategic co-optation of emerging powers into international institutions, see Kruck and Zangl (2019).
} 
In addition to the importance conferred to the participation of its Key Partners in its committees and subsidiary bodies, and especially as associate members, the OECD also tried to institutionalize specific cooperation agreements with each country. Indonesia signed its framework agreement in 2012, China's Ministry of Commerce signed a memorandum of agreement in 2014, and the cooperation agreement with Brazil was signed in 2015, considered the most ambitious one, for envisaging a highest number of possibilities of convergence to OECD legal instruments as well as the acceptance of peer reviews of public policies (Godinho 2018).

\section{Brazil's increasing engagement among the Key Partners}

From 2006 to 2015, Brazil's participation in OECD committees and bodies has increased from 14 to 24 , South Africa's from 8 to 23, China's from 2 to 6, India's from 5 to 12, and Indonesia's from 1 to 7 , showing an increased engagement from all these countries in this period, but Brazil above them all. Regarding the adherence to OECD legal instruments, from 2006 to 2016, Brazil has increased its adherence from 15 to 30 instruments, South Africa from 8 to 18, China from 4 to 7 , India from 4 to 11 , and Indonesia from 3 to 10 , also revealing the intense engagement on the part of the Brazilian government towards the organization (Godinho 2018).

\section{Figure 2. Adherence of Key Partners to OECD Legal Instruments}

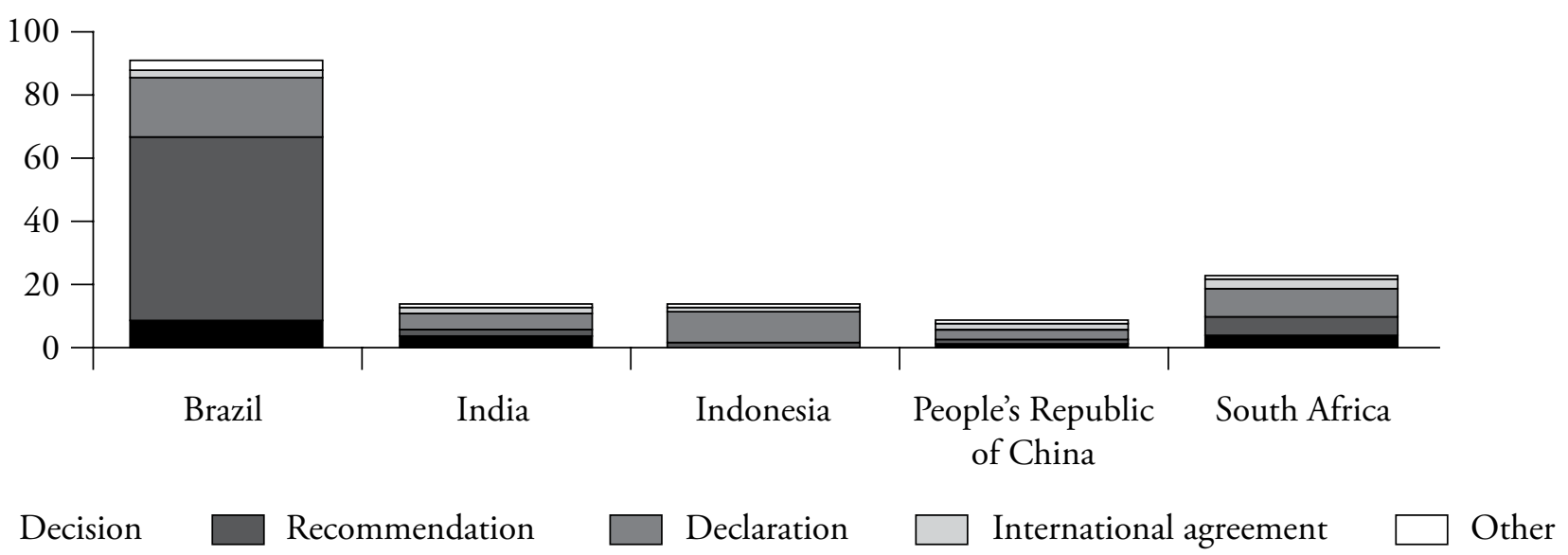

Source: Organization for Economic Co-operation and Development (2020c)

Since then, Brazil was the only country, among the Key Partners, to have formally presented its candidacy for a full membership. Indonesia and the four other members of the BRICS grouping have not expressed an increased interest in full membership. Therefore, Brazil has remained the only BRICS country that is seeking to be part of the OECD. In February 2020, Brazil had adhered to 81 OECD legal instruments and requested adherence to other 65 instruments, amounting to 146 out of the 254 current legal instruments of the OECD (Ministério das Relaçóes Exteriores 2020) 


\section{Recent Members and new candidacies}

The most recent countries to join the OECD as full members were Latvia in 2016, Lithuania in 2018 and Colombia in 2020 (Organization for Economic Co-operation and Development 2020a). The only country presently in the category of candidate for accession is Costa Rica, whose accession process began in 2015. In May 2020, shortly after the announcement that Colombia became the $37^{\text {th }}$ member of the organization, Costa Rica received the Council's invitation and is set to become the $38^{\text {th }}$ member, as soon as it deposits its instrument of accession to the OECD Convention (Organization for Economic Co-operation and Development 2020b).

The OECD Council is formally assessing the candidacies of six prospective members: Brazil, Argentina, Peru, Romania, Croatia and Bulgaria. In 2017, the existence of these several new candidacies, at a moment when the organization had already reached 35 members and still had three accession processes on course, led to discussions among its members regarding the purposes and risks of expansion (Cozendey 2019). As a result, the OECD approved a Framework for the Consideration of Prospective Members, defining the most important legal instruments to be considered as evidence of convergence with the organization's values and practices: the Declaration on International Investment and Multinational Enterprises; the Policy Framework for Investment; the Convention on Combating Bribery of Foreign Public Officials in International Business Transactions; the Corporate Governance Principles; a framework on taxation and profit shifting; the Code of Liberalization of Capital Movements and the Code of Liberalization of Current Invisible Operations (Organization for Economic Co-operation and Development 2017).

Therefore, it establishes that a prospective member's commitment to an OECD instrument is demonstrated by adherence to these instruments, progress towards adherence to such instruments, or by how its policies, laws, regulations and practices are aligned with the measures and practices required by the instrument, together with the assessment of the degree of "like-mindedness" towards the organization's fundamental values. In that sense, the OECD's new framework has brought the most significant part of the accession process to the pre-candidacy phase, in order to previously assess the commitment of its prospective members, who therefore anticipate the adherence of domestic legislations and the internalization of the OECD's standards as a way to strengthen their candidacies. The OECD acknowledges that the formal accession process itself, with the full participation of the relevant committees, represents a powerful transformative instrument to secure a country's convergence with the values and standards of the organization. While in theory the new procedures were designed to promote a pragmatic approach to the pre-selection of its candidates, the accession process remains essentially political, setting high entry barriers and concentrating the most intense pressures on this critical phase (Cozendey 2019; Davis 2016). After a country is admitted, the only direct channel for pressure is the peer review mechanism (often referred as the peer pressure mechanism), considered an effective tool in inducing reforms 
on the part of an organization that doesn't count on coercive norms, police power or a dispute settlement body (Fernandes 2017; Florêncio and Seyffarth 2018).

With respect to the OECD's institutional features, the Framework for the Consideration of Prospective Members has affirmed the commitment to remain open to new members, while also determining that it doesn't need to be universal to be effective. The OECD identifies itself as a unique multilateral organization in the international architecture, which does not aim to become a universal organization in terms of size, but rather to ensure that its standards and policies are applied and implemented on a global scale (Organization for Economic Co-operation and Development 2017).

The enlargement process, however, has not been consensual among the OECD's most prominent members. On one hand, European countries have demonstrated clear support to enlargement, as long as it promotes the entrance of the European Union members that have not yet acceded to the OECD, therefore demanding a matching process of enlargement between European countries and candidates from other regions. The United States, on the other hand, had first indicated its preference for the maintenance of the size of the organization in respect to the number of full members, even though it had actively supported the accession of Israel in 2010. This position was attributed to resistance on the part of the State Department, rather skeptical regarding the entrance of developing countries whose degree of "like-mindedness" might not be sufficient and could therefore undermine the main features of the organization (Frenkel 2017). However, it later evolved to a position of supporting the accession of Latin American countries, in the matching process with the entrance of European countries.

Since then, unlike previous accession rounds, the current process of enlargement has shown that there are regional dynamics at play. Prospective members are exclusively from Eastern Europe and Latin America, and there are no longer considerations on the possibility of new full members from other regions, suggesting a retreat from global reach ambitions and a return to an institutional arrangement closer to its European and North American origins. In this context, in Latin America, the enlargement process became a sequencing movement instead of previous individual approaches, as were the cases of Mexico in 1994, and Chile in 2010.

\section{The Brazilian candidacy}

Brazil formally presented its request to open an accession process to the OECD in May 2017, during Michel Temer's administration, who expected that the initial approval could be obtained at very short term, and that the negotiating process could proceed at a fast pace, before the presidential elections of the end of 2018 and the end of his mandate in the beginning of 2019. As already mentioned, this was not the first time that Brazil considered becoming a member of the OECD as part of a foreign policy oriented towards closer relationships with developed countries and a deeper integration to global economic governance. In July 1995, 
President Fernando Henrique Cardoso announced that Brazil would become a member of the OECD before the end of his mandate, in 1998. At that time, the purpose of achieving a full membership at short term did not progress, but it inaugurated a process of increased participation for Brazil in several committees and legal instruments of the OECD in different areas. The country had already integrated the OECD Development Centre in 1994. In 1996, Brazil began an active engagement with the organization's committees by joining the steel committee as a full member and quickly expanding its involvement, the next year, to participate in some of the most important committees, including trade, investment and competition policy. In 1999, the OECD Council launched a program directed at Brazil and, since then, the country has been invited to all ministerial meetings in the organization (Organization for Economic Co-operation and Development 2018a). In 2003, the Ministry of Finance has created the National Contact Point (NCP), in accordance with the OECD Guidelines for multinational enterprises, to which Brazil had adhered in 1997, when it started to participate in the Committee on International Investment and Multinational Enterprises. The NCP functions as an interministerial working group which seeks to promote the implementation of the OECD's Guidelines in Brazil and to receive the allegations of inobservance resulting from the action or omissions on the part of multinational enterprises (Thorstensen and Gullo 2018).

As a result of the Enhanced Engagement launched by the OECD in 2007, to increase contacts with Brazil, China, India, Indonesia and South Africa, the Brazilian government has signed its cooperation agreement with the OECD in 2015, under the presidency of Dilma Rousseff. Stemming from an intense mobilization on the part of the Ministry of Finance, under an administration already more committed to a liberal economic agenda than its predecessors, the signing of the Brazil-OECD Cooperation Agreement in 2015 suggests that a reorientation of the country's foreign economic relations was already underway before the change of government which took place after the presidential impeachment process in 2016.

While Brazil's relationship with the OECD had previously been largely stimulated by the organization's initiative to approach a group of emerging economies, this was followed by a period of greater relevance of domestic determinants. In 2015, in the context of a very serious deterioration of the country's macroeconomic indicators, the new team appointed at the head of the Ministry of Finance took the lead in conducting the country's relations with the OECD (Godinho 2018). After Michel Temer took office in May 2016, Brazil's accession to the organization was given the highest priority, under the argument that it would represent a seal of quality for the country's economic policies before global economic actors, as well as a crucial stimulus to attract international investment. From an alternative perspective, however, the new urgency conferred to the goal of becoming a full member of the OECD could suggest an attempt to institutionalize mechanisms to promote the "lock-in" of economic reforms before the elections of December 2018, embedding domestic rules in an international institution in order to prevent the possibility of backlash.

The Finance Ministry has assumed, since 2016, the leading role in Brazil's relation with the OECD. In 2018, together with the President of the Central Bank, the Minister formally required 
to the OECD Secretary-General adherence to the Code of Liberalization of Capital Movements and the Code of Liberalization of Current Invisible Operations, which are considered the opening doors for an accession to a full membership in the organization. The codes are structured as general rules, to which a list of exceptions negotiated for the new entrant is annexed. Whereas in several other international treaties the list of country reservations to the codes reflects unilateral declarations by the new member, in the OECD the reservations to the codes of liberalization have to be negotiated and accepted by the countries that are already members (Cozendey 2019).

According to the Ministry of Finance's presentation on the accession process, once accepted, Brazil would become the greatest emerging market to have economic rules and governance fully compatible with OECD standards, enjoying a privileged position as the only country to be a member both in the OECD and the BRICS grouping (Ministério da Fazenda 2018). Among the six prospective members that have officially required the opening of accession discussions, Brazil is considered in the OECD to be the country presenting the highest compatibility with the organization's norms (Organization for Economic Co-operation and Development 2018b, 8).

The accession process is expected to proceed along the following phases:

1. The formal request by the prospective country to open an accession process.

2. Should the Council agree to open accession discussions with a prospective member, the Secretary-General will proceed to prepare the "Accession Roadmap" for adoption by the Council, defining specific terms for each country.

3. The prospective member presents an "Initial Memorandum," specifying its position in respect to the 250 legal instruments of the OECD.

4. Technical reviews by the OECD and meetings with representatives of the prospective member.

5. Final decision, by unanimity, by the Council of the OECD.

6. Signing of the Agreement of Accession to the OECD Convention.

7. Approval by the National Congress and ratification of the agreement.

8. Deposit of the Accession Agreement and full membership in the OECD.

Since the beginning of the Bolsonaro administration, in March 2019, the issue of the country's accession to the OECD gained new momentum, in part due to the highest priority conferred by the Ministry of the Economy, but also because of the new dimension acquired, at presidential level, when the Brazilian President requested the support of the United States' President. The result was the acceptance of conditionality at a bilateral level and a crossed bargaining between negotiations in two different international institutions in relation to renouncing special and differentiated treatment for developing countries in WTO negotiations.

In June 2019, as he celebrated the signing of the agreement between Mercosur and the European Union, the Minister of the Economy explained that this agreement, together with the accession to the OECD, would guarantee the gradual opening of the Brazilian economy. At this time, however, very little has been said regarding the magnitude of the agenda to be deployed in 
parliament, not only for the ratification of the agreements signed at the international level, but also in respect to their internalization, requiring significant changes in domestic legislations in numerous areas, especially in taxation matters. In that sense, the internalization of the norms involved in the country's accession to the OECD might result in an unprecedented politicization of the parliament's role in international issues, with very diverse positions regarding, for instance, the environmental norms embodied in the OECD.

According to the Brazilian government, as well as other prospective members, the main advantage in acceding to the OECD consists in promoting an improved business environment in order to have a positive impact on investors' perceptions, which should result in higher levels of investment. In the Brazilian case, in addition to the major impact expected on business perceptions, there is also a diplomatic argument regarding the possibility that, as a full member, the country might expand its influence on the OECD's decision-making processes regarding elaboration of new norms in the organization, which is considered a prominent agenda setter for the future of global governance. In the context of the crisis of multilateralism in universalist institutions, the OECD has promoted the consolidation of a particular type of multilateralism, together with a strengthened governance which is significantly expanding its members and issues. ${ }^{5}$

\section{Latin American countries and the United States' role in the OECD}

Latin America is nowadays the region where the OECD is expanding its members in a matching process with the incorporation of European members. Mexico was the first Latin American country to integrate the organization in 1994, followed by Chile in 2010 and Colombia in 2020. Costa Rica is now set to become the $38^{\text {th }}$ member of the OECD, as well as the fourth in the region, while Argentina, Brazil and Peru are prospective members that have already formally requested the opening of their accession processes.

The case of Mexico's accession to the OECD must be understood in the context of its negotiations to join NAFTA. It was the first enlargement of the second wave of the OECD's expansion, in the post-Cold War era, and was a very symbolic and practical expression of Mexico's commitment to economic liberalization as well as closer relations with developed countries. Having already agreed to pursue a free trade agreement with the United States and Canada in 1990, the announcement in the following year that it intended to join the OECD was a complementary step in broadening the scope of its economic reforms. While the ratification of NAFTA was still uncertain, the OECD membership was also viewed as a way to promote a "lock-in" of its economic reforms in case NAFTA were rejected in the United States' Congress (Davies 2016). Both Mexico

\footnotetext{
${ }^{5}$ In May 2019, the OCDE became the first intergovernmental organization to adopt Principles on Artificial Intelligence, to guide governments in designing national legislation and set a global reference on the matter, illustrating the constant expansion of the OECD's norms and its capacity to influence global governance in new areas to be regulated (Cozendey 2019). The OECD's then 36 member countries, along with Argentina, Brazil, Colombia, Costa Rica, Peru and Romania, signed up to the OECD Principles on Artificial Intelligence.
} 
and Korea, when acceding to the OECD, were formally required to withdraw from the G77, where they were founding members, reflecting the view that belonging to these groupings was considered, at that time, mutually exclusive strategies. Later, the Mexican and the Korean cases both served as warnings regarding the destabilizing effects of the rush to membership, as the banking reforms and capital inflows were in a significant way responsible for their subsequent financial crises (Davies 2016).

In the case of Chile, the accession process was the result of the OECD's initiative, in 2007, to promote a new wave of enlargement, and was concluded in 2010, together with Israel, Slovenia and Estonia. Although the Chilean economy was already acknowledged for its commitment to liberalization and market reforms, accession to the OECD was not an easy process, as complex economic reforms were necessary to reach the required standards, particularly in the banking sector and pensions funds (Saéz 2010; "Do Latin American members benefit from the OECD?" 2019). The process, however, evolved at a rapid pace and was concluded after fourteen months.

Costa Rica began accession discussions in 2015 and was finally invited to accede to the organization's Convention in May 2020. The roadmap the OECD established for this country in 2015 was identical to the one defined for Colombia in 2013. The main areas under examination concerned issues related to corporate governance and governmental transparency. A former trade minister of Costa Rica has reported that the support of the United States was decisive throughout the process and that, while the accession process has very demanding technical components, it is ultimately a political decision ("Do Latin American members benefit from the OECD?” 2019).

Colombia initiated its accession talks in 2013 and was finally invited to become the $37^{\text {th }}$ member of the OECD in May 2018, together with the announcement of the country's new status as a "Global Partner" of the North Atlantic Treaty Organization (NATO). As part of its accession process, Colombia has been subjected to in-depth reviews by 23 OECD Committees and has introduced major reforms to align its legislation, policies and practices to OECD standards, including labor issues, the reform of the justice system, corporate governance of state-owned enterprises, anti-bribery, trade, as well as new national policies on industrial chemicals policy and waste management (Organization for Economic Co-operation and Development 2018a). Throughout the process, the United States raised numerous obstacles. It had conditioned its support to the acceptance of new commitments related to intellectual property rights, demanding specific norms that go beyond those established in the OECD on that matter, demonstrating the purpose of extracting high level concessions from new entrants and even an agenda that can be viewed as "OECD plus," restating the intent to advance the "WTO plus" agenda that was not accomplished in the multilateral trade negotiations.

In addition to direct pressure, the accession process of Latin American countries also suggests that political motivations and electoral calendars were clearly reflected in the scaling of the list of prospective members. In May 2019, the Secretary-General of the OECD proposed the immediate accession of Argentina and Romania, leaving the entrance of Brazil and Peru to a subsequent 
moment (Rittner 2019; Vasconcelos 2019). The urgency which was then conferred to Argentina indicated the intent to launch the accession process before a possible change of government in the presidential elections in the second semester, in an attempt to “lock-in" Argentina's engagement toward the OECD. The Secretary-General also insistently expressed the idea that Argentina's candidacy should be maintained as State policy (Niebieskikwiat 2019). Considering the deteriorating economic circumstances in Argentina and the election of President Alberto Fernández, the accession to the OECD is no longer a priority.

The United States' position on the OECD enlargement gained greater visibility throughout the year of 2019, starting during Brazilian President Jair Bolsonaro's official visit to Washington. President Donald Trump announced then that he would support the Brazilian candidacy (Ministério da Relaçóes Exteriores 2019), reverting his previous opposition established in 2017, when Brazil had gained the support of all OECD members, with the sole exception of the United States (Cozendey 2017). The new position, however, came with a condition, as Brazil had to accept foregoing the special and differential treatment dispensed to developing countries in the WTO negotiations.

A few months later, Secretary of State Michael Pompeo specified that, despite supporting the Brazilian candidacy, at the moment, Washington only backed the membership candidacies of Argentina and Romania, as the United States continued to prefer enlargement at a measured pace, taking into account the need to press for governance and succession planning at the OECD (Adghimi and Sink 2019). Indeed, the resistance of the United States to the OECD enlargement has its origins before the Trump administration. During the Obama administration, the State Department already opposed a rushed enlargement process, as it could affect the homogeneity of shared purposes among its members if it was to incorporate developing countries that might undermine the institution's operational capacity.

Although the State Department recognized the relevance of the technical work undertaken in the OECD's committees, it also criticized the excessive expansion of issue areas in the organization, referring in particular to the issue of labor standards. The United States have expressed increased opposition to a process which is understood as a private agenda of the Secretary-General, who has frequently pressed for a rapid process of enlargement, based on the assessment that the future relevance of the organization depends on its ability to attract emerging economies and developing countries (Freitas 2017). The idea of strengthening the OECD as a pillar in the architecture of global economic governance has not been valued in the United States' government, in the context of the Trump administration's uncertainties regarding any kind of international institution.

The position of the Secretary of State indicated that enlargement should take into account the need to put additional pressure for economic reforms in the functioning of the organization. There are actually different positions at stake regarding an antagonism between, on the one hand, a strategy of accelerated expansion attempting to promote the "lock-in" of domestic policies in accordance with electoral calendars and, on the other, the Unites States' interest in 
reassessing the functioning of the OECD in order to strengthen the possibilities to press other members, especially the new ones, regarding their commitments to the organization's guidelines and beyond.

Finally, in respect to the Peruvian candidacy, it has been supported by the Secretary-General in the context of the integration of all the Latin American members of the Pacific Alliance, an initiative of regional integration comprised by Chile, Colombia, Mexico and Peru, established in 2011 for the promotion of free trade and international business, with a clear orientation towards Pacific Asia. Peru was amongst the first countries to engage with the organization through an OECD Country Program, which was built around five key areas: economic growth; public governance, anti-corruption and transparency; human capital and productivity; and environment. It was also the first non-member state to announce the intention of adhering to the Code of Liberalization of Capital Movements and the Code of Liberalization of Current Invisible Operation, expressing the considerable degree of convergence of its domestic practices and legislations with the OECD's instruments. Peru also achieved the support of the United States during 2019, but not the priority which was then attributed to Argentina.

\section{Conclusion}

This article has examined the OECD enlargement process as an important dimension for understanding variations in groupings, organizations and global governance mechanisms in contemporary international relations. In the context of the well-acknowledged crisis of multilateralism in universalist organizations, it has described how the OECD has moved forward in the strengthening of a particular type of multilateralism, based on selective membership as well as in the deepening and expansion of a solid framework for global economic governance. Reflecting uncertainties at the global level, the OECD has acquired new institutional purposes and geographical outreach as an expression of what was once depicted as some expanded version of a liberal Greater West in which some of the emerging states might have been absorbed - although highly unlikely in the case of most BRICS members.

In the case of Brazil, public debate on the implications of its candidacy to a full membership has been limited and dominated by enthusiastic views and interests on the matter. Considering the complexity of the adjustments required to the internalization of the normative framework of the OECD, as well as the high costs involved in the negotiations of the accession process, mobilization of broader domestic support will probably foster debates on the matter, which for the moment is mainly understood as an issue of symbolic status for diplomatic purposes. In this context, as Brazil has become the most active non-member of the OECD in terms of participation in committees and legal instruments, there could be a possibility of an attempt to innovate through an institutional strategy aiming to keep the "à la carte" pattern of relationship the country has already established with this unique multilateral body. 


\section{References}

Adghimi, S., and J. Sink. "Trump says he still supports Brazil in OECD, despite letter." Bloomberg, October 10, 2019.

Carroll, P., and A. Kellow. The OECD: a study of organizational adaptation. Cheltenham: Edward Elgar, 2011.

Clifton, J., and D. Diaz-Fuentes. "Is the organization for economic cooperation and development ready for China?" Emerging Markets, Finance and Trade 50, no. 6, (2014): 21-36. doi: https://doi.org/10.1080/1540496X.2014.1013842

Clifton, J., and D. Diaz-Fuentes. "The OECD and phases in the international political economy, 1961-2011." Review of International Political Economy 18, n. 5 (2011): 552-569. doi: https://doi.org/10.1080/09692290.2011.620464

Council at Ministerial Level. "OECD council resolution on enlargement and enhanced engagement.” OECD Home, May 16, 2007. https://www.oecd.org/brazil/ oecdcouncilresolutiononenlargementandenhancedengagement.htm

Cozendey, C. M. “O pedido de acessão do Brasil à OCDE: onde estamos.” Cadernos de Politica Exterior 5, no. 8 (2019): 49-76.

Cozendey, C. M. “O pedido de acessão do Brasil à OCDE: aceder a quê? Aceder porquê?” Revista Brasileira de Comércio Exterior 31, no. 132 (2017): 26-32.

Davis, C. More than just a rich country club: membership conditionality and institutional reform in the OECD. Working Paper. Princeton, NJ: Princeton University, 2016.

"Do Latin American members benefit from the OECD?" Latin America Advisor, April 5, 2019. Fernandes, J. A. C. "O Brasil e a OCDE: uma visão sobre o sistema de acesso e o papel da participação empresarial.” Revista Brasileira de Comércio Exterior 31, n. 132 (2017): 20-25.

Florêncio, S. A. L. and A. S. Seyffarth. "OCDE: o ponto de inflexão necessário na política externa brasileira." In Politica externa brasileira em debate: dimensóes e estratégias de inserção internacional no pós-crise de 2008, edited by S. A. L. Florencio, W. A. Desiderá Neto, H. Ramanzini Junior, E. B. Silva Filho, 189-206. Brasília, DF: Fundação Alexandre de Gusmão, 2018.

Freitas, A. "Os tropeços no caminho do Brasil rumo à OCDE.” Nexo Jornal, December 10, 2017. Frenkel, A. "América Latina y su fiebre por el club de los ricos." Nueva Sociedad Opinión, July 7, 2017.

Godinho, R. O. A OCDE em rota de adaptaçáo ao cenário internacional: perspectivas para o relacionamento do Brasil com a organização. Brasília, DF: Fundação Alexandre de Gusmão, 2018.

Hurrell, A. "Narratives of emergence: rising powers and the end of the third world?" Brazilian Journal of Political Economy 33, no. 2 (2013): 203-221. doi: https://doi.org/10.1590/S0101-31572013000200001 
Kruck, A., and B. Zangl. "Trading privileges for support: the strategic co-optation of emerging powers into international institutions." International Theory 11, no. 3 (2019): 318-343. doi: https://doi.org/10.1017/S1752971919000101

Mello, F. C. O Brasil e o multilateralismo contemporâneo. Texto para discussão IPEA. Brasília, DF: Instituto de Pesquisa Econômica Aplicada, 2011.

Ministério da Fazenda. Organização para a Cooperação e Desenvolvimento Econômico OCDE. Brasília, DF, 2018. http://www.fazenda.gov.br/assuntos/atuacao-internacional/ cooperacao-internacional/ocde

Ministério das Relaçóes Exteriores. "Comunicado conjunto de presidente Jair Bolsonaro e do presidente Donald J. Trump.” Comunicados, March 19, 2019. http://www.itamaraty.gov. $\mathrm{br} / \mathrm{pt}$-BR/notas-a-imprensa/20186-comunicado-conjunto-do-presidente-donald-j-trumpe-do-presidente-jair-bolsonaro-19-de-marco-de-2019

Ministério das Relações Exteriores. "Intervenção do ministro Ernesto Araújo no café da manhã sobre o ingresso do Brasil na OCDE." Ministro das Relaçóes Exteriores Discursos, February 13, 2020. http://www.itamaraty.gov.br/pt-BR/discursos-artigos-e-entrevistascategoria/ministro-das-relacoes-exteriores-discursos/21331-intervencao-do-ministroernesto-araujo-no-cafe-da-manha-sobre-o-ingresso-do-brasil-na-ocde-brasilia-13-02-2020

Niebieskikwiat, N. "La OCDE pide que la Argentina sostenga su plan de ingreso al organismo como una política de Estado.” Clarín Política, October 19, 2019.

Organization for Economic Co-operation and Development - OECD. OECD council revised resolution on partnerships in OECD bodies. Paris, 2015. https://www.oecd.org/globalrelations/partnershipsinoecdbodies/C(2012)100-REV1-FINAL-En.pdf.

Organization for Economic Co-operation and Development - OECD. Report of the chair of the working group on the future size and membership of the organisation to the council: framework for the consideration of prospective members. Paris, 2017. http://www.oecd.org/ mcm/documents/C-MIN-2017-13-EN.pdf.

Organization for Economic Co-operation and Development - OECD. OCDE economic surveys: Brazil 2018. Paris, 2018a. https://www.oecd-ilibrary.org/economics/oecdeconomic-surveys-brazil-2018_eco_surveys-bra-2018-en

Organization for Economic Co-operation and Development - OECD. Active with Brazil. Paris, 2018b. http://www.oecd.org/brazil/Active-with-Brazil.pdf

Organization for Economic Co-operation and Development - OECD. Accession of Costa Rica to the Organisation. Paris, 2020b. http://www.oecd.org/officialdocuments/publicdisplayd ocumentpdf $/$ cote $=\mathrm{C}(2020) 41 /$ FINAL $\&$ docLanguage $=$ En

Organization for Economic Co-operation and Development - OECD. "Global OECD welcomes Colombia as its 37th member”. OECD Home, April 28, 2020a. https://www.oecd.org/colombia/global-oecd-welcomes-colombia-as-its-37th-member.htm Organization for Economic Co-operation and Development - OECD. OECD legal instruments. Paris, 2020c. https://legalinstruments.oecd.org/en/stats 
Patrick, S., and N. Egel. "Economic coalition of the willing: the OECD reinvents itself." Foreign Affairs, March 11, 2015.

Rittner, D. "Diretor da OCDE propóe ingresso de Argentina e Romênia antes do Brasil." Valor Econômico, May 20, 2019.

Saéz, R. E. "La OCDE y el ingreso de Chile." Estudios Internacionales 166, (2010): 93-112.

Thorstensen, V., and M. F. Gullo. Brasil na OCDE: membro pleno ou mero espectador? CCGI Working Paper 479. São Paulo, SP: Fundação Getúlio Vargas, 2018.

Vasconcelos, G. "Ingresso do Brasil pode levar até cinco anos, diz diretor da OCDE." Valor Econômico, June 18, 2019.

Woodward, R. The Organization for Economic Cooperation and Development. London: Routledge, 2009. 